\title{
Pengembangan Aplikasi Panduan dan Reward untuk Pemandu dan Pelaku Usaha Wisata di Kota Yogyakarta Berbasis Android
}

\author{
Irkham Huda $^{\mathrm{a} 1}$, Cerry Surya Pradana ${ }^{\mathrm{b} 2}$, Shafira Putri Ananda ${ }^{\mathrm{a} 3}$, Hanif Wafi Septyapramudita ${ }^{\mathrm{a} 4}$, Rizky \\ Kurniawan ${ }^{\text {a5 }}$ \\ ${ }^{a}$ Departemen Teknik Elektro dan Informatika, Sekolah Vokasi, Universitas Gadjah Mada \\ Sekip Unit I, Blimbingsari Caturtunggal, Depok, Sleman, Yogyakarta 55281 \\ 1irkhameugm.ac.id \\ ${ }^{3}$ shafira.p.a@mail.ugm.ac.id \\ ${ }^{4}$ hanifwafiemail.ugm.ac.id \\ ${ }^{5}$ rizkykurniawan@mail.ugm.ac.id \\ ${ }^{b}$ Departemen Bahasa, Sastra, dan Manajemen Budaya, Sekolah Vokasi, Universitas Gadjah Mada \\ Sekip Unit I, Blimbingsari Caturtunggal, Depok, Sleman, Yogyakarta 55281 \\ ${ }^{2}$ cerrysuper@ugm.ac.id
}

\begin{abstract}
Abstrak
Pariwisata selalu menjadi salah satu sektor penting dalam pembangunan ekonomi di Indonesia. Sektor pariwisata menawarkan beberapa jenis pekerjaan yang memungkinkan warga lokal memanfaatkannya, antara lain pemandu wisata (tour guide) dan pelaku usaha (bisnis) pendukung wisata seperti penginapan, kuliner, oleh-oleh atau cinderamata. Pemandu wisata perlu informasi tempat wisata dan rekomendasi usaha pendukung wisata yang tepat bagi wisatawan. Pelaku usaha juga perlu menjalin komunikasi dengan pemandu wisata untuk promosi usahanya, keduanya saling membutuhkan.Dalam penelitian ini penulis mengembangkan media untuk menjembatani kepentingan pemandu wisata dengan para pelaku usaha pendukung wisata dalam bentuk aplikasi yang berisi panduan direktori wisata dan terdapat fitur promosi bagi pelaku usaha serta fitur reward bagi pemandu wisata. Aplikasi dikembangan berbasis Android dengan manajemen dashboardnya berbasis web. Dari hasil pengujian fungsional aplikasi sudah dapat berjalan dengan baik sesuai kebutuhan.
\end{abstract}

Kata kunci: Pariwisata, Pemandu Wisata, Pelaku Usaha, Reward, Android

\section{Development of Android Based Guides And Reward Applications For Tourist Guiders And Businesses In Yogyakarta City}

\begin{abstract}
Tourism has always been one of the important sectors in economic development in Indonesia. The tourism sector offers several types of jobs that allow local residents to take advantage of it, including tour guides and business supporting tourism such as lodging, culinary, gifts or souvenirs. Tour guides need information on tourist attractions and good tourism support businesses recommendations for the tourists. Business actors also need to establish communication with tour guides to promote their business, both need each other.In this study, the authors develop the media to bridge the interests of tour guides with tourism supporting business actors in the form of an application containing tour directory guides and promotional features for business actors and reward features for tour guides. Applications are developed based on Android with a web-based dashboard management. From the results of functional testing the application can run properly as needed.
\end{abstract}

Keywords: Tourism, Tour Guides, Business actors, Reward, Android

\section{Pendahuluan}

Berdasarkan data BPS pada tahun 2019 tercatat kontribusi Pariwisata terhadap PDB Nasional sebesar 8\%, dengan jumlah kunjungan wisatawan manca negara sebesar 20 juta, wisatawan dalam negeri sebesar 275 juta, dan total devisa 240 triliun rupiah [1]. Di Kota Yogyakarta sendiri menurut laporan Dinas Pariwisata Kota Yogyakarta jumlah kunjungan antara tahun 2016-2018 terus mengalami peningkatan dengan rincian 2016 sebanyak 3,5 juta, 2017 sebanyak 3,8 juta, serta 2018 sejumlah 4,1 juta. Hal ini menunjukkan potensinya yang sangat besar. [2]

Menurut Inskeep [3], terdapat beberapa komponen pengembangan pariwisata yang berkaitan dengan pendekatan perencanaan pariwisata, yaitu atraksi wisata, akomodasi, fasilitas dan pelayanan pendukung wisata lainnya (amenitas), transportasi, dan infrastruktur 
(aksesibilitas). Selain itu sektor pariwisata menawarkan beberapa jenis pekerjaan yang memungkinkan warga lokal memanfaatkannya sehingga dapat mengurangi angka pengangguran jika dikelola dengan baik. Contoh lapangan usaha tersebut adalah pemandu wisata (tour guide) dan usaha-usaha (business) pendukung wisata seperti penginapan, kuliner, oleh-oleh, dan cinderamata.

Pemandu wisata disebut juga pramuwisata atau dalam Bahasa Inggris disebut tour guide, merupakan seseorang yang bertugas memberikan bimbingan, penjelasan, dan petunjuk tentang obyek wisata dan dituntut untuk dapat memberikan informasi dan rekomendasi pendukung kegiatan wisata kepada wisatawan seperti penginapan, kuliner, maupun tempat membeli oleh-oleh atau cinderamata. Pemandu wisata dinilai penting karena menjadi referensi utama bagi pengunjung wisata di tempat lokasi tersebut [4], sehinggu pemandu wisata perlu untuk terus memperluas pengetahuannya tentang obyek wisata dan pelaku usaha pendukung wisata. Bagi pelaku usaha pendukung wisata untuk meningkatkan penghasilan perlu juga menjalin hubungan atau koneksi dengan para pemandu wisata sehingga para wisatawan mendapatkan informasi dan rekomendasi untuk berkunjung ke tempat usahanya.

Dengan kemajuan teknologi informasi dewasa ini kepentingan pemandu wisata dan pelaku usaha ini dapat dihubungkan dan dijalin dengan mengembangkan sebuah media berbasis teknologi yang sesuai. Dikutip dari data laporan Digital Around The World in 2019[5] jumlah pengguna aktif smartphone di Indonesia lebih dari 130 juta orang dilihat dari data pengguna sosial media di aplikasi mobile. Baik pemandu wisata maupun pelaku usaha pun banyak yang sudah terbiasa menggunakan smartphone untuk komunikasi sehari-hari, sehingga pengembangan aplikasi pada smartphone terutama berbasis Android dapat menjadi media yang tepat untuk menjebatani kepentingan pemandu wisata dan pelaku usaha wisata tersebut.

Terdapat beberapa penelitian sebelumnya terkait pengembangan aplikasi pemandu wisata ini. Rizky Fitriyanto, dkk [4] melakukan penelitian pembuatan aplikasi Pemandu O-Tour Guide Indonesia Berbasis Android. O-Tour Guide merupakan aplikasi penyewaan pemandu wisata yang memiliki fitur pencarian lokasi, menampilkan profil hingga lisensi kerja pemandu wisata. Aplikasi O-Tour Guide ini memadukan metode Sistem Pengambilan Keputusan Simple Additive Weighting yang guna mempermudah wisatawan untuk memilih pemandu wisata. Surasa, dkk [7] mengembangkan aplikasi yang bertujuan untuk menerapkan teknologi Google Maps API dalam aplikasi pemandu wisata berbasis Android. Hasil rancangan sistem diimplementasikan menggunakan App Inventor, PHP, dan database MySQL. Hasil pengujian menunjukkan aplikasi layanan pemandu wisata dapat digunakan untuk mengakses informasi wisata tentang Kabupaten Selayar. Ningrum, dkk[8] melakukan pengembangan sistem informasi yang dapat saling mengintegrasikan antara objek wisata, penginapan dan transportasi, sehingga wisatawan dapat menjangkau seluruh objek-objek wisata berikut penginapan dan transportasi yang dapat digunakan menuju objek wisata yang diinginkan. Dimana dalam penelitian ini akan memberikan nilai tambah berupa penambahan fungsifungsi pada aplikasi yang dapat diakses melalui internet dan memberikan saran kepada para wisatawan, objek wisata mana saja yang dapat dijangkau dari titik dimana keberadaan mereka saat ini.

Penelitian yang akan penulis lakukan berbeda dengan penelitian-penelitian sebelumnya yang sudah disebutkan walaupun sama-sama mengembangkan Aplikasi terkait tempat wisata, pemandu wisata dan pelaku usaha. Penelitian yang akan penulis lakukan akan mengembangkan aplikasi yang berisi panduan direktori dan reward untuk pemandu dan pelaku usaha pendukung wisata di Kota Yogyakarta berbasis Android yang diharapkan mampu menjembatani keduanya.

\section{METODOLOGI}

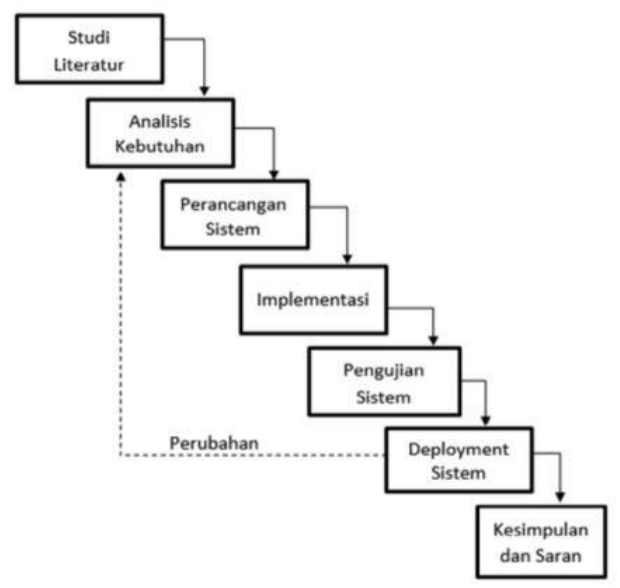

Gambar 1. Model pengembangan sistem agile SDLC

Pada penelitian ini tahapan model pengembangan sistem yang digunakan diadaptasi dari model Agile SDLC seperti terlihat pada Gambar 1. Dimana metode tersebut memiliki 7 fase yaitu studi literature, analisis kebutuhan, perancangan, implementasi, pengujian, deployment sistem, serta kesimpulan dan saran. Kemudian fase-fase dari analisis kebutuhan sampai deployment sistem tersebut akan diulang kembali jika terjadi perubahan atau penambahan fitur sesuai kebutuhan.

\section{A. Studi Literatur}

1) Android: adalah sebuah sistem operasi yang dikembangkan oleh Google. Android dibuat khusus untuk smartphone dan tablet, meskipun pada perkembangan selanjutnya Android bisa digunakan pasa perangkat TV pintar, mobil pintar, atau jam tangan pintar.. Android juga mempunyai lebih dari 2 miliar pengguna aktif [9].

2) Laravel: merupakan framework berbasis PHP yang sifatnya open source dan menggunakan konsep model view - controller. Laravel berada di bawah lisensi MIT License dengan menggunakan Github sebagai tempat berbagi code menjalankannya [10]

3) Application Programming Interface (API): adalah antarmuka komputasi yang mendefinisikan interaksi antara beberapa perantara perangkat lunak. API dapat 
menghubungkan aplikasi untuk kolega, mitra, atau pengembang pihak ketiga untuk mengakses data dan layanan untuk membangun aplikasi dengan cepat [11].

4) Pemandu Wisata (Tour Guide): adalah seseorang yang memandu wisatawan dan menginterpretasikan warisan budaya serta alam dari suatu daerah. Pemandu wisata merupakan orang yang membawa wisatawan untuk melakukan kunjungan (ekskursi) dalam jangka waktu tertentu [12].

5) Pelaku Usaha Wisata (Merchant): menurut UU Nomor 10 Tahun 2009 pasal 1 ayat 7, usaha pariwisata merupakan usaha yang menyediakan barang dan/atau jasa bagi pemenuhan kebutuhan wisatawan dan penyelenggaraan pariwisata [6]. Beberapa contoh pelaku usaha wisata seperti penginapan, kuliner, oleh-oleh, dan cinderamata.

\section{B. Analisis Kebutuhan}

Dalam menyelesaikan permasalahan yang dihadapi pemandu dan pelaku usaha wisata, maka perlu dikembangkan aplikasi dengan arsitektur sistem berbasis Client-Server yang terdiri dari 3 bagian utama :

1) Aplikasi Web Dashboard untuk Admin: merupakan aplikasi berbasis web yang akan digunakan oleh admin untuk mengelola data-data aplikasi, yaitu data pengguna (pemandu wisata dan pelaku usaha), data tempat wisata, data kota wisata, data merchant (toko, penginapan, dan rumah makan), data promo, data reward bagi pemandu wisata, statistik pengguna aplikasi, dan laporan transaksi. Admin juga dapat mengelola informasi sebagai notifikasi untuk dibagikan ke pengguna.

2) Aplikasi Android untuk Tour Guide dan Merchant: merupakan aplikasi berbasis mobile yang dapat digunakan pemandu wisata (guide) untuk melihat lokasi dan informasi detail tempat-tempat wisata dan tempat-tempat pelaku usaha wisata (merchant). Pemandu wisata juga dapat melihat promosi dari pelaku usaha kemudian dapat dibagikan kepada wisatawan untuk bertransaksi dengan pelaku usaha melalui kode QR sehingga dapat memberikan poin bagi pemandu wisata. Selain itu pemandu wisata juga dapat menukarkan poin yang dikumpulkan dengan reward yang disediakan oleh sistem. Selain itu aplikasi ini juga digunakan pelaku usaha wisata (toko, rumah makan, penginapan). Untuk pelaku usaha wisata terdapat fasilitas untuk mengubah data profil tempat usahanya sendiri dan menambahkan informasi produk/layanan dijual dan informasi promonya, selain itu juga terdapat fasilitas scan kode QR untuk validasi transaksi.

3) Backend API: merupakan antarmuka penghubung untuk komunikasi antara aplikasi Android yang berperan sebagai client dengan basis data aplikasi di server yang dikelola dengan web dashboard.

\section{Perancangan Sistem}

Untuk membuat rancangan aplikasi agar mudah diimplementasikan digunakan diagram Use Case dan Entity Relationship Diagram (ERD).
1) Use case diagram: merupakan gambaran atau rancangan fungsionalitas pada sebuah sistem atau aplikasi yang akan dikembangkan [13]. Use Case dapat menggambarkan fungsionalitas sistem aplikasi berdasarkan pembagian hak akses penggunanya. Berdasarkan hasil analisis kebutuhan terdapat 3 aktor pengguna yaitu admin, pemandu wisata (guide), dan pelaku usaha wisata (merchant) maka diagram use case dapat dilihat pada Gambar 2. Dapat dilihat pada diagram, pengguna admin dapat mengakses fungsionalitas yang ada dalam aplikasi Web Dashboard untuk mengelola data pengguna, tempat wisata, merchant, notifikasi, promo, reward, kota wisata, dan melihat laporan dan data transaksi. Untuk pengguna guide dapat mengakses fungsionalitas pada aplikasi Android, seperti untuk registrasi, melihat lokasi dan informasi tempat wisata, melihat lokasi dan informasi merchant, melihat promo dan menggenenerate kode QR untuk bertransaksi, melihat, dan menukarkan reward. Untuk pengguna merchant dapat mengakses fungsional pada aplikasi Android juga tetapi berbeda dengan akses yang dimiliki guide, seperti megelola informasi merchant, mengelola item merchant, mengelola promo, dan menscan kode QR.

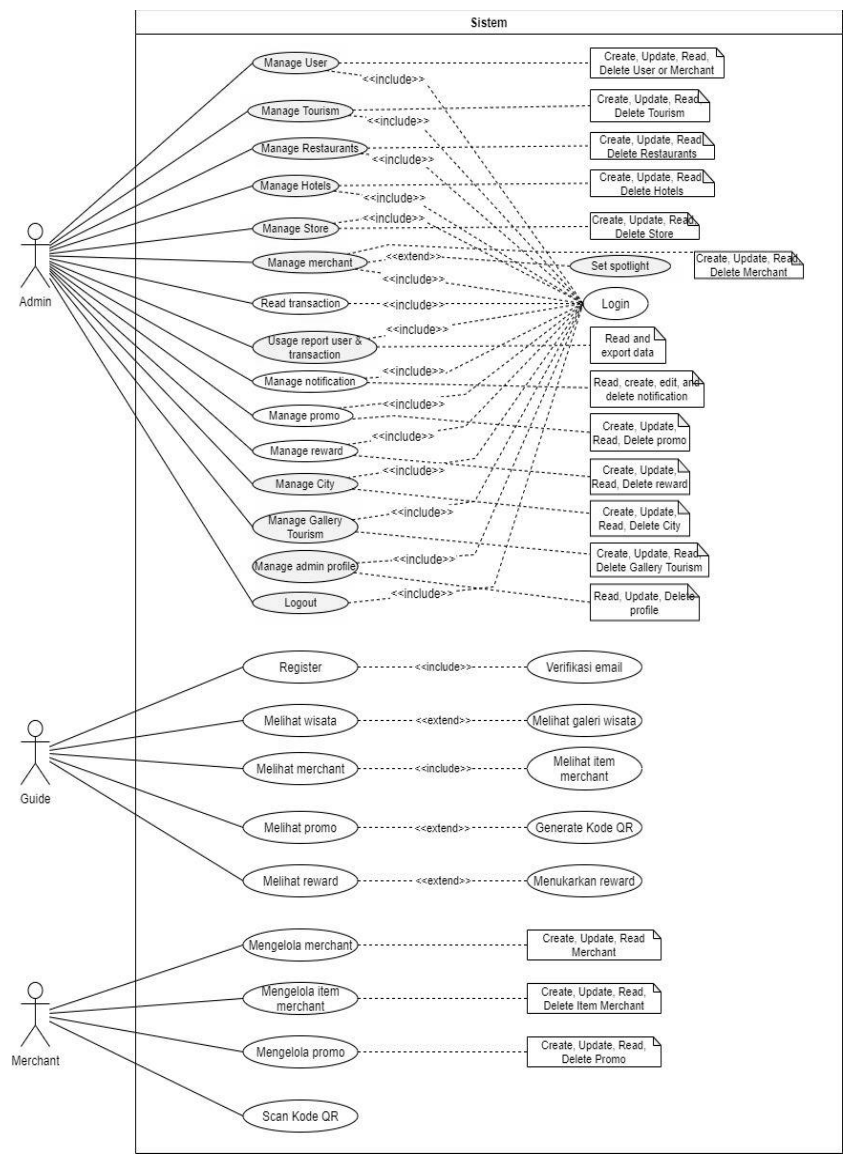

Gambar 2. Diagram use case aplikasi

2) Entity Relationship Diagram (ERD): Rancangan basis data digambarkan dengan Entity Relationship Diagram (ERD). ERD merupakan model data berupa notasi grafis dalam pemodelan data konseptual yang menggambarkan hubungan antara tempat penyimpanan. ERD melengkapi penggambaran grafik dengan struktur logika, dengan kata lain menggambarkan arti dari aspek 
seperti, bagaimana entitas-entitas, atribut-atribut, dan relasi. ERD Aplikasi Panduan dan Reward dapat dilihat pada Gambar 3.

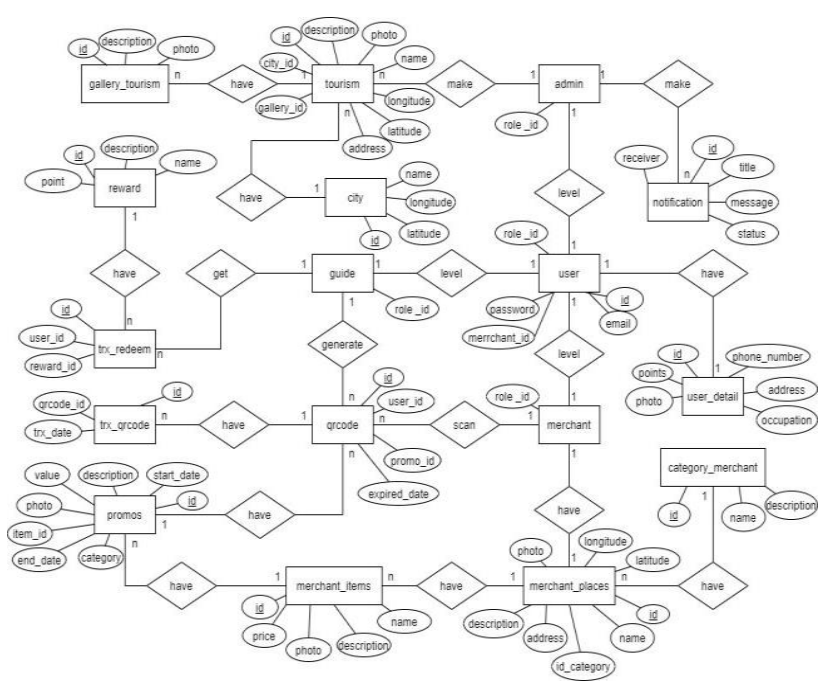

Gambar 3 Tabel ER diagram aplikasi

Basis data sistem aplikasi terdiri dari 15 tabel seperti terlihat pada Gambar 3. Tabel-tabel tersebut adalah:

- Tabel roles, digunakan untuk menyimpan daftar role yang ada di dalam sistem untuk menentukan jenis pengguna yang terdapat dalam sistem.

- Tabel users, digunakan untuk menyimpan data pengguna yang terdaftar di dalam sistem. Tabel ini berfungsi untuk proses autentikasi pengguna saat mengakses sistem.

- Tabel user_detail, digunakan untuk menyimpan informasi pribadi mengenai pengguna.

- Tabel merchants, digunakan untuk menyimpan informasi merchant (tempat pelaku usaha) pada suatu kota.

- Tabel category_merchant, untuk menyimpan jenis-jenis kategori merchant yang terdapat pada sistem.

- Tabel merchant_items, digunakan untuk menyimpan item-item yang terdapat dalam suatu merchant.

- Tabel promos, digunakan untuk menyimpan promo yang telah dibuat oleh suatu merchant.

- Tabel rewards, digunakan untuk menyimpan hadiah yang dapat ditukarkan dengan poin oleh pengguna dengan jenis guide.

- Tabel trx_reedem, digunakan untuk menyimpan setiap transaksi pengklaiman pengguna terhadap rewards yang disediakan oleh sistem.

- Tabel qrcode, digunakan untuk menyimpan setiap kode QR yang dibuat oleh pengguna dengan jenis guide terhadap suatu promo yang ada.

- Tabel trx_qrcode, digunakan untuk menyimpan setiap kode QR yang berhasil dipindai dan digunakan untuk traksaksi pada suatu merchant.

- Tebel tourism, digunakan untuk menyimpan data mengenai suatu tempat wisata yang ada pada suatu kota.

- Tabel tourism_gallery, digunakan untuk menyimpan galeri foto terhadap suatu tempat wisata yang dapat dilihat oleh pengguna.
- Tabel city, digunakan untuk menyimpan data suatu kota yang terdaftar di dalam sistem.

- Tabel notifications, digunakan untuk menyimpan notifikasi yang dibuat dan dikirim ke perangkat yang digunakan oleh pengguna.

\section{HASIL DAN PEMBAHASAN}

\section{A. Implementasi}

Implementasi sistem aplikasi web dashboard menggunakan Laravel versi 6.0, bahasa pemrograman PHP 7, dan text editor Visual Studio Code. Bagian aplikasi Android baik untuk pengguna Guide maupun Merchant diimplementasikan dengan IDE Android Studio dengan bahasa pemrograman Java dan tampilan user interface disusun dengan XML. Untuk implementasi API menggunakan Laravel versi 6.0, bahasa pemrograman PHP 7, text editor Visual Studio Code, dan uji coba API menggunakan Postman versi 7.26. API meliputi keseluruhan data yang dibutuhkan pada aplikasi mobile. API diimplementasikan dengan arsitektur REST yang filosofi desain yang mendorong kita untuk menggunakan protokol dan fituryang sudah ada pada Web untuk memetakan permintaan terhadap sumber daya pada berbagai macam representasi dan manipulasi data di Internet [14]. Bentuk web service menggunakan REST style sangat cocok digunakan sebagai backend dari aplikasi berbasis mobile karena cara aksesnya yang mudah dan hasil data yang dikirimkan berformat JSON sehingga ukuran file menjadi lebih kecil. JavaScript Object Notation (JSON) merupakan format pertukaran data yang ringan, mudah dibaca dan ditulis oleh manusia, serta mudah diterjemahkan dan dibuat (generate) oleh komputer [15]. Untuk basis data seluruh bagian sistem mengakses basis data yang sama yang diimplementasikan menggunakan MySQL.

Implementasi antarmuka aplikasi web dashboard secara umum dapat dilihat pada Gambar 4. Setelah pengguna admin login maka akan ditampilakan halaman utama yang berisi informasi jumlah data yang terdaftar pada masingmasing menu yaitu jumlah guide, jumlah merchant, jumlah tempat wisata, dan jumlah total transaksi. Selain itu terdapat penjelasan fungsional setiap menu. Untuk mengakses menu-menu lain pengguna dan klik pada menu sidebar.

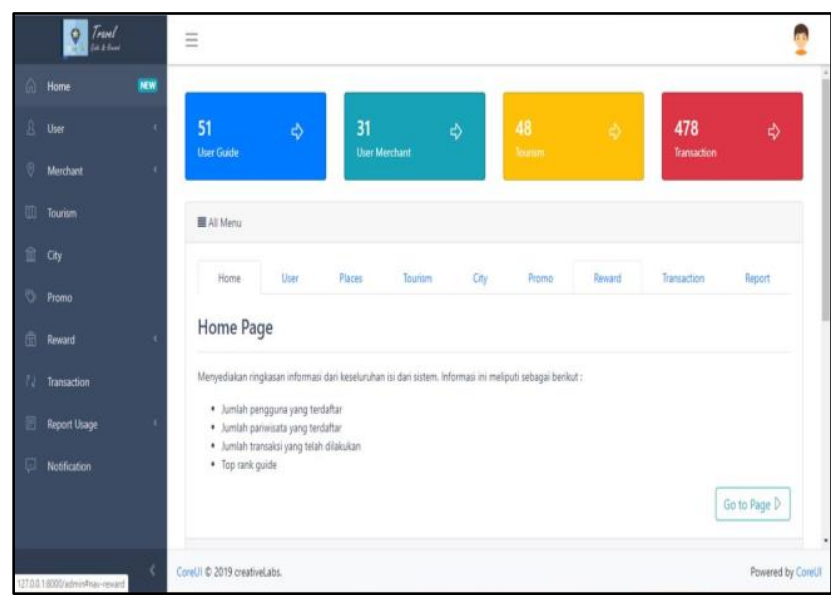

Gambar 4 Halaman utama aplikasi web dashboard aplikasi 
Implementasi antarmuka aplikasi Android bagi pengguna guide pada merchant pada halaman home memiliki tampilan yang sama terdapat peta lokasi dan daftar nama lokasi untuk tempat wisata dan merchant dapat di filter pada tab berdasarkan rekomendasi, tourism (tempat wisata), hotel (penginapan), souvenir (toko), dan food (rumah makan) dapat dilihat pada Gambar 5.

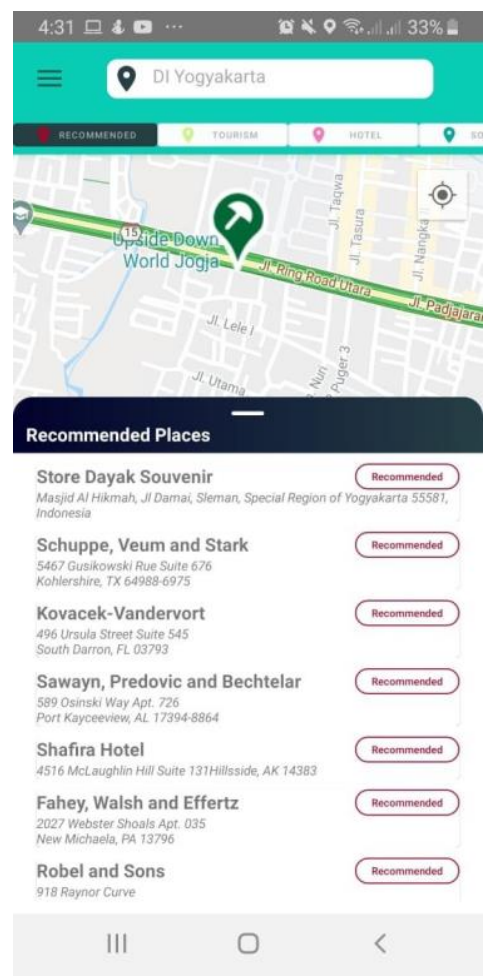

Gambar 5. Antarmuka aplikasi mobile di halaman home

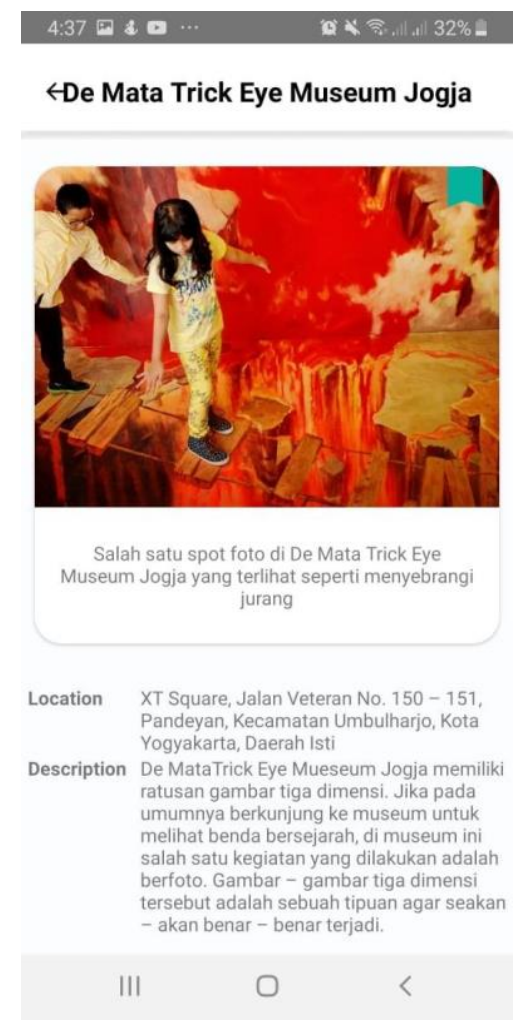

Gambar 6. Antarmuka aplikasi halaman detail tempat wisata
Implementasi halaman detail tempat wisata dapat dilihat pada Gambar 6, menampilkan foto galeri dan detail informasinya. Implementasi halaman detail merchant dapat dilihat pada Gambar 7, menampilkan informasi detail dari tempat usaha merchant beserta daftar item yang dijual beserta promonya. Item promo jika dipilih akan menampilkan halaman detail promo beserta kode QR yang bisa dibagikan dan digunakan untuk validasi transaksi dengan merchant tersebut, dapat dilihat pada Gambar 8 .

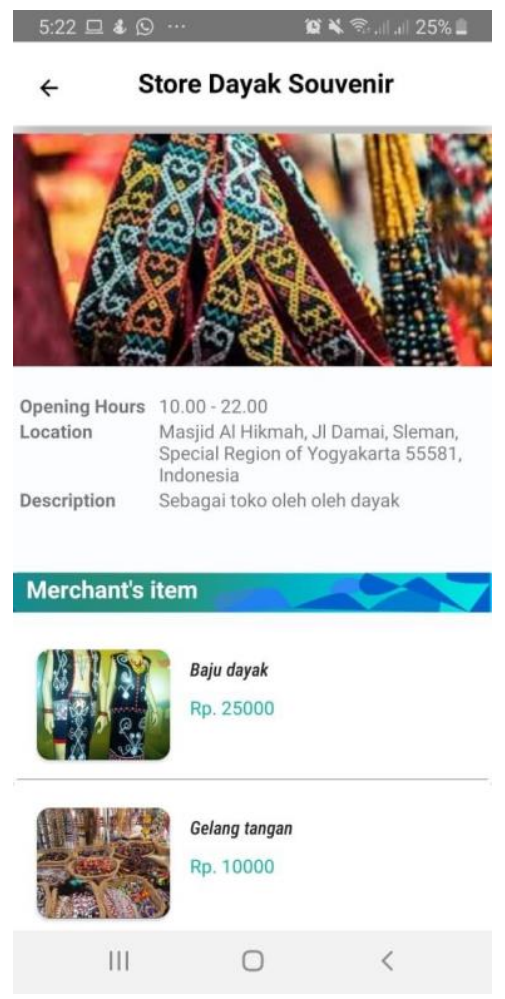

Gambar 7. Antarmuka aplikasi mobile detail merchant

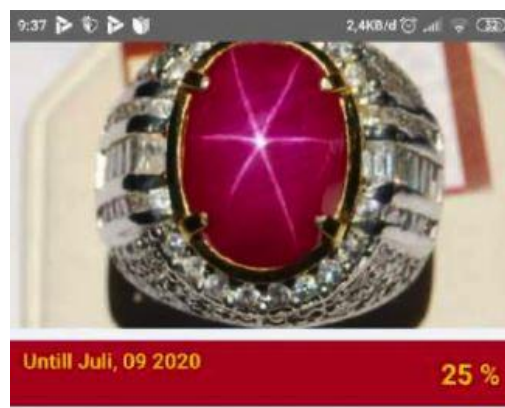

Batu akik bacan merah muda, dapat memanjakan mata

Untuk harga teman

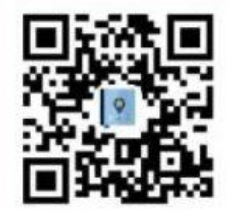

SAVE

요

Gambar 8. Halaman detail promo dan kode QR 
Implementasi antarmuka bagi pengguna merchant sedikit berbeda dari pengguna guide, pada merchant terdapat halaman edit merchant pada profil merchant yang dikelola, seperti pada Gambar 9.

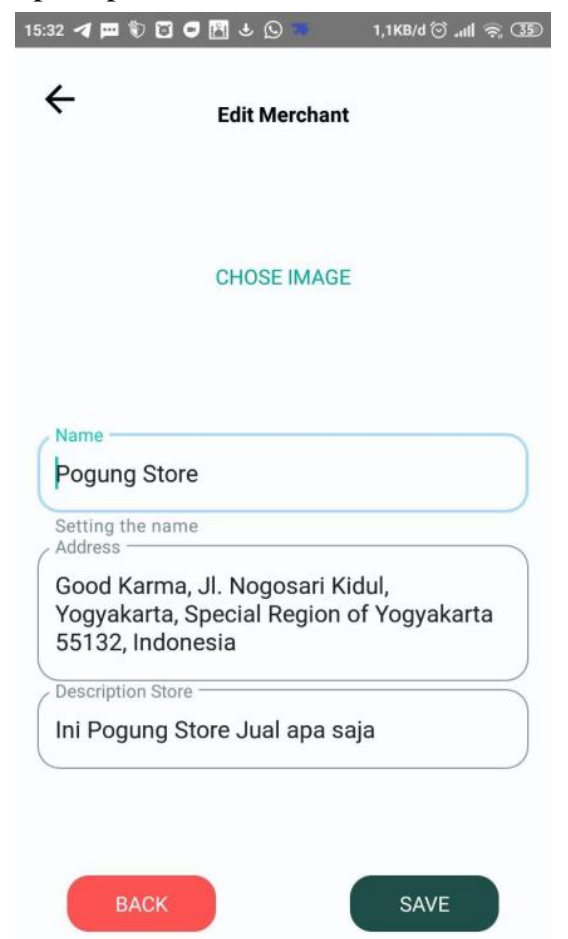

\section{Gambar 9. Antarmuka aplikasi halaman edit merchant}

Pengguna merchant juga bisa menambahkan daftar item yang dijual di tempat usahanya pada halaman Add an Item seperti pada Gambar10. Selain itu pengguna juga bisa menambahkan promo pada item yang sudah ditambahkan pada halaman Add promo, dapat dilihat pada Gambar 11.

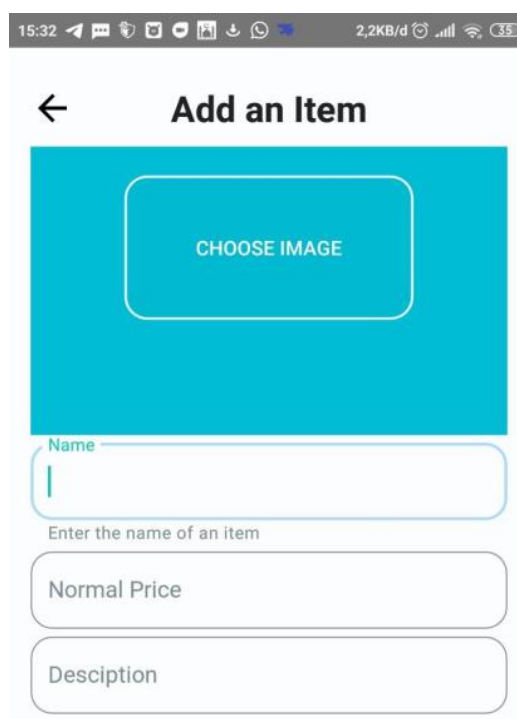

SAVE

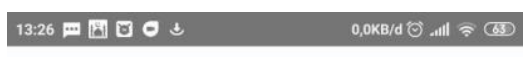

\section{$\leftarrow \quad$ Add Promo}

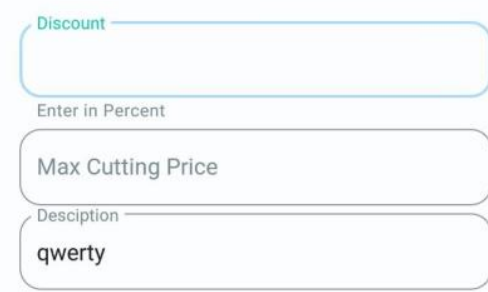

$$
\begin{aligned}
& \text { Setting the start date } \\
& \text { 2020-07-06 } \\
& \text { Setting the end date } \\
& \text { 2012-12-12 }
\end{aligned}
$$

\section{ADD}

Pengguna merchant juga bisa melihat daftar promo pada tempat usahanya yang sudah ditambahkan pada halaman Promo Inventory, implementasi antarmukanya dapat dilihat pada Gambar 12. Pada halaman tersebut merchant bisa menghapus atau mengupdate promo yang sudah dibuat sebelumnya.

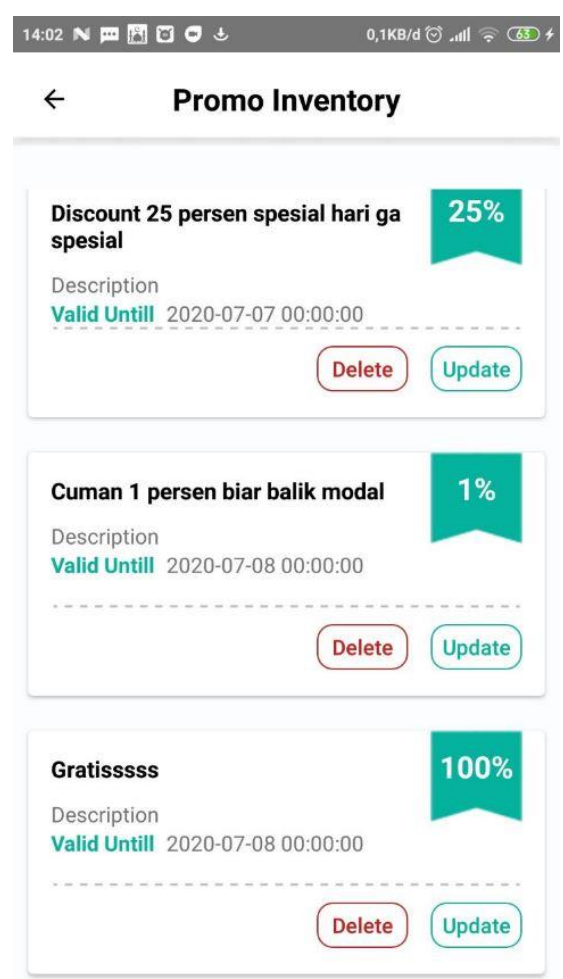

Gambar 12. Antarmuka aplikasi halaman promo inventory 
Pada pengguna aplikasi merchant juga terdapat menu untuk scan kode QR yang berfungsi untuk validasi transaksi dengan pengguna Guide. Implementasi antarmuka halaman scan kode QR dapat dilihat pada Gambar 13.

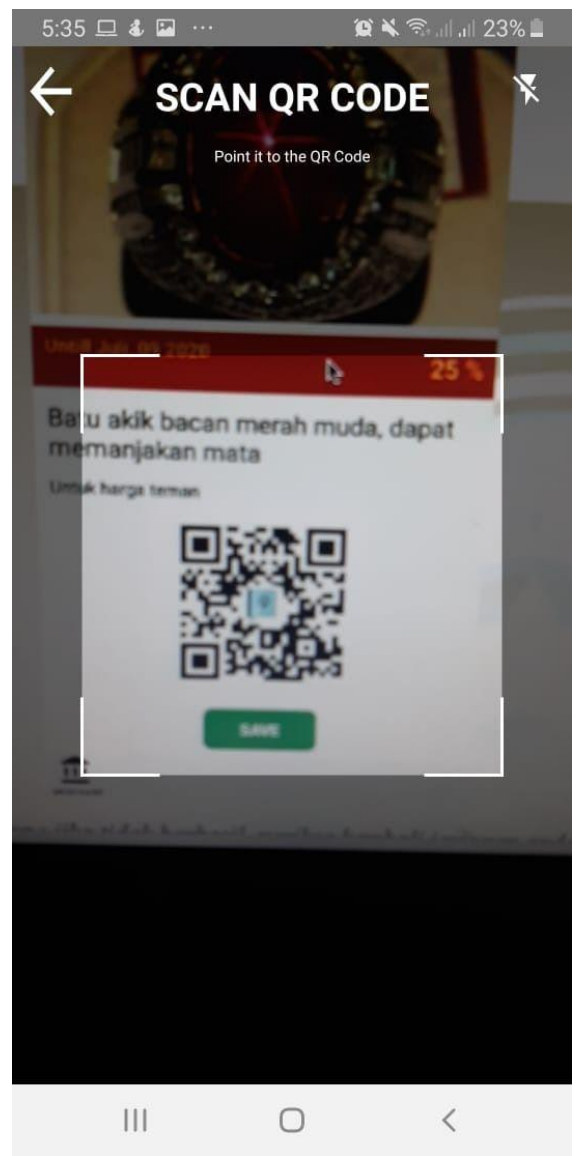

Gambar 13. Antarmuka aplikasi mobile halaman scan kode QR

\section{B. Pengujian}

Pengujian dilakukan untuk menjamin kualitas aplikasi dan juga mengetahui kelemahan aplikasi. Pada pengujian aplikasi ini digunakan metode Blackbox, metode ini terdiri dari set kondisi input, baik yang secara sengaja atau tidak sengaja, valid atau tidak valid, dengan mempraktekkan semua keperluan atau persyaratan fungsional dari suatu program. Pengujian blackbox dilakukan selama tahaptahap akhir pengujian. Hasil pengujian aplikasi diberikan pada tabel 1 untuk pengguna Guide, tabel 2 untuk pengguna Merchant, dan tabel 3 untuk pengguna Admin.

TABEL I

HASIL PENGUJIAN APLIKASI UNTUK PENGGUNA GUIDE

\begin{tabular}{|l|l|l|l|}
\hline No & Kasus uji & Prosedur & Hasil uji \\
\hline 1 & $\begin{array}{l}\text { Login Aplikasi } \\
\text { sebagai Guide }\end{array}$ & $\begin{array}{l}\text { Masukkan email Guide dan } \\
\text { passwordnya }\end{array}$ & Valid \\
\hline 2 & $\begin{array}{l}\text { Daftar email } \\
\text { Guide }\end{array}$ & Masukkan form pendaftaran & Valid \\
\hline 3 & $\begin{array}{l}\text { Menyimpan } \\
\text { kode QR }\end{array}$ & Menyimpan kode QR & Valid \\
\cline { 3 - 4 } & $\begin{array}{l}\text { Pemberitahuan kecil berhasil } \\
\text { menyimpan }\end{array}$ & Valid \\
\hline 4 & $\begin{array}{l}\text { Hadiah } \\
\text { (Reward })\end{array}$ & Melihat daftar hadiah & Valid \\
\cline { 3 - 4 } & & Melihat gambar hadiah & Valid \\
\hline
\end{tabular}

\begin{tabular}{|c|c|c|c|}
\hline & & $\begin{array}{l}\text { Melihat point yang } \\
\text { dibutuhkan hadiah }\end{array}$ & Valid \\
\hline & & $\begin{array}{l}\text { Melihat Pop up berhasil } \\
\text { mendapatkan promo }\end{array}$ & Valid \\
\hline & & Mengurangi point pengguna & Valid \\
\hline \multirow[t]{4}{*}{5} & \multirow[t]{4}{*}{ Promo } & Melihat daftar promo & Valid \\
\hline & & $\begin{array}{l}\text { Melihat detil toko dari promo } \\
\text { terkait }\end{array}$ & Valid \\
\hline & & Melihat Point & Valid \\
\hline & & $\begin{array}{l}\text { Melihat besar dari daftar } \\
\text { masing masing promo }\end{array}$ & Valid \\
\hline \multirow[t]{4}{*}{6} & \multirow[t]{4}{*}{ Detil toko } & Melihat deskripsi toko & Valid \\
\hline & & Melihat gambar toko & Valid \\
\hline & & $\begin{array}{l}\text { Melihat daftar produk yang } \\
\text { ditawarkan }\end{array}$ & Valid \\
\hline & & $\begin{array}{l}\text { Melihat promo produk pada } \\
\text { produk tertentu }\end{array}$ & Valid \\
\hline \multirow[t]{3}{*}{7} & \multirow[t]{3}{*}{ Lokasi terkini } & Melihat lokasi pengguna & Valid \\
\hline & & Penyaring kategori usaha & Valid \\
\hline & & Melihat marker pada peta & Valid \\
\hline
\end{tabular}

TABEL III

Hasil PenguJian APliKasi UNTUK PENGGUNA MERCHANT

\begin{tabular}{|c|c|c|c|}
\hline No & Kasus uji & Prosedur & Hasil uji \\
\hline 1 & $\begin{array}{l}\text { Login Aplikasi } \\
\text { sebagai pemilik } \\
\text { toko }\end{array}$ & $\begin{array}{l}\text { Masukkan email toko dan } \\
\text { passwordnya }\end{array}$ & Valid \\
\hline \multirow[t]{3}{*}{2} & \multirow[t]{3}{*}{ Lokasi terkini } & Melihat lokasi pengguna & Valid \\
\hline & & Melihat kategori toko & Valid \\
\hline & & Melihat marker pada peta & Valid \\
\hline \multirow[t]{4}{*}{3} & \multirow[t]{4}{*}{ Promo toko } & Melihat daftar promo toko & Valid \\
\hline & & Melihat nilai promo & Valid \\
\hline & & Update promo & Valid \\
\hline & & Delete Promo & Valid \\
\hline \multirow[t]{2}{*}{4} & \multirow[t]{2}{*}{ Toko } & Edit toko & Valid \\
\hline & & Tambah produk & Valid \\
\hline \multirow[t]{2}{*}{5} & \multirow[t]{2}{*}{ Produk toko } & Hapus produk & Valid \\
\hline & & Memperbarui produk & Valid \\
\hline \multirow[t]{2}{*}{6} & \multirow{2}{*}{$\begin{array}{l}\text { Menerjemahkan } \\
\text { kode QR }\end{array}$} & Menerjemahkan kode QR & Valid \\
\hline & & Melihat Pop up berhasil & Valid \\
\hline
\end{tabular}

Pengujian blackbox aplikasi mobile dilakukan setelah aplikasi diintegrasikan dengan API. Hasil pengujian dapat dilihat pada tabel I dan tabel II bahwa seluruh fungsional aplikasi mobile baik pada pengguna Guide maupun Merchant dapat berjalan dengan baik.

TABEL IIIII

HASIL PENGUJIAN APLIKASI UNTUK PENGgUNA ADMIN

\begin{tabular}{|c|c|c|c|}
\hline No. & Kasus Uji & Prosedur & Hasil Uji \\
\hline 1 & Login sistem & Isi data masukan & Valid \\
\hline 2 & $\begin{array}{l}\text { Ubah data dan } \\
\text { password } \\
\text { admin }\end{array}$ & Isi data masukan & Valid \\
\hline 3 & $\begin{array}{l}\text { Ubah avatar } \\
\text { admin }\end{array}$ & Isi data masukan & Valid \\
\hline 4 & $\begin{array}{l}\text { Tambah data } \\
\text { akun guide }\end{array}$ & Isi data masukan & Valid \\
\hline 5 & $\begin{array}{l}\text { Ubah data } \\
\text { akun guide }\end{array}$ & Isi data masukan & Valid \\
\hline 6 & $\begin{array}{l}\text { Hapus data } \\
\text { akun guide }\end{array}$ & $\begin{array}{l}\text { Pilih tombol icon merah } \\
\text { "trash" }\end{array}$ & Valid \\
\hline
\end{tabular}




\begin{tabular}{|c|c|c|c|}
\hline No. & Kasus Uji & Prosedur & Hasil Uji \\
\hline 7 & $\begin{array}{l}\text { Mengatur } \\
\text { status aktif } \\
\text { akun guide }\end{array}$ & Pilih toogle on-off & Valid \\
\hline 8 & $\begin{array}{l}\text { Lihat detail } \\
\text { akun guide }\end{array}$ & Pilih tombol icon biru "info" & Valid \\
\hline 9 & $\begin{array}{l}\text { Tambah data } \\
\text { akun merchant }\end{array}$ & Isi data masukan & Valid \\
\hline 10 & $\begin{array}{l}\text { Ubah data } \\
\text { akun merchant }\end{array}$ & Isi data masukan & Valid \\
\hline 11 & $\begin{array}{l}\text { Hapus data } \\
\text { akun merchant }\end{array}$ & Pilih icon merah "trash" & Valid \\
\hline 12 & $\begin{array}{l}\text { Mengatur } \\
\text { status aktif } \\
\text { akun merchant }\end{array}$ & Pilih toogle on-off & Valid \\
\hline 13 & $\begin{array}{l}\text { Tambah data } \\
\text { merchant }\end{array}$ & Isi data masukan & Valid \\
\hline 14 & $\begin{array}{l}\text { Ubah data } \\
\text { merchant }\end{array}$ & Isi data masukan & Valid \\
\hline 15 & $\begin{array}{l}\text { Hapus data } \\
\text { merchant }\end{array}$ & Pilih icon merah "trash" & Valid \\
\hline 16 & $\begin{array}{l}\text { Lihat lokasi } \\
\text { merchant dari } \\
\text { peta }\end{array}$ & Pilih icon kuning "pin" & Valid \\
\hline 17 & $\begin{array}{l}\text { Tambah data } \\
\text { wisata }\end{array}$ & Isi data masukan & Valid \\
\hline 18 & $\begin{array}{l}\text { Ubah data } \\
\text { wisata }\end{array}$ & Isi data masukan & Valid \\
\hline 19 & $\begin{array}{l}\text { Hapus data } \\
\text { wisata }\end{array}$ & Pilih icon merah "trash" & Valid \\
\hline 20 & $\begin{array}{lr}\text { Lihat } & \text { lokasi } \\
\text { wisata } & \text { dari } \\
\text { peta } & \\
\end{array}$ & Pilih icon kuning "pin" & Valid \\
\hline 21 & $\begin{array}{ll}\text { Lihat detail } \\
\text { wisata }\end{array}$ & Pilih icon hijau "info" & Valid \\
\hline 22 & $\begin{array}{l}\text { Tambah data } \\
\text { foto wisata }\end{array}$ & Isi data masukan & Valid \\
\hline 23 & $\begin{array}{l}\text { Hapus data } \\
\text { foto wisata }\end{array}$ & Pilih icon merah "trash" & Valid \\
\hline 24 & $\begin{array}{l}\text { Tambah data } \\
\text { kota }\end{array}$ & Isi data masukan & Valid \\
\hline 25 & $\begin{array}{l}\text { Ubah data } \\
\text { kota }\end{array}$ & Isi data masukan & Valid \\
\hline 26 & $\begin{array}{l}\text { Hapus data } \\
\text { kota }\end{array}$ & Pilih icon merah "trash" & Valid \\
\hline 27 & $\begin{array}{l}\text { Lihat lokasi } \\
\text { kota dari peta }\end{array}$ & Pilih icon kuning "pin" & Valid \\
\hline 28 & $\begin{array}{l}\text { Memfilter data } \\
\text { pengguna } \\
\text { berdasarkan } \\
\text { bulan dan } \\
\text { tahun }\end{array}$ & Pilih icon biru "filter" & Valid \\
\hline 29 & $\begin{array}{l}\text { Mengunduh } \\
\text { data pengguna } \\
\text { menjadi file } \\
\text { export excel }\end{array}$ & Pilih icon biru "download" & Valid \\
\hline 30 & $\begin{array}{l}\text { Memfilter data } \\
\text { transaksi } \\
\text { berdasarkan } \\
\text { bulan dan } \\
\text { tahun }\end{array}$ & Pilih icon biru "filter" & Valid \\
\hline 31 & $\begin{array}{l}\text { Mengunduh } \\
\text { data transaksi } \\
\text { menjadi file } \\
\text { export excel }\end{array}$ & Pilih icon biru "download" & Valid \\
\hline
\end{tabular}

Pengujian pada pengguna Admin dilakukan pada aplikasi web dashboard, dari hasil pengujian pada tabel III dapat dilihat seluruh fungsional aplikasi dapat berjalan dengan baik.

\section{KESIMPULAN}

Kesimpulan yang diperoleh setelah dilakukan pengembangan Aplikasi Panduan dan Reward untuk Pemandu Wisata dan Pelaku Usaha Wisata adalah:

1. Berhasil dibangun sistem aplikasi Panduan dan Reward yang terdiri dari aplikasi berbasis Android bagi pengguna Guide dan Merchant, dashboard berbasis web bagi pengguna Admin, dan API untuk integrasi sistem aplikasi sesuai dengan analisis kebutuhannya.

2. Berdasarkan hasil pengujian, semua fungsional aplikasi sesuai skenario pengujian yang ditetapkan dapat berjalan dengan baik sehingga aplikasi layak digunakan.

\section{DAFTAR PUSTAKA}

[1] Badan Pusat Statistik (BPS), "Statistik Kunjungan Wisatawan Mancanegara 2019" .

[2] Dinas Pariwisata Kota Yogyakarta, "Laporan Kinerja Dinas Pariwisata Tahun Anggaran 2018".

[3] A. D. Nabila \& D. Widiyastuti, "Kajian Atraksi, Amenitas dan Aksesibilitas untuk Pengembangan Pariwisata Umbul Ponggok di Kabupaten Klaten," Jurnal Bumi Indonesia, Volume 7, Nomor 2, 2018.

[4] R. Fitriyanto, E. Handriyantini, \& J. Ericka, "Sistem Informasi Penyedia Pemandu Wisata dengan Metode Simple Additive Weighting (SAW) Berbasis Android," Jurnal of Information Technology STIKI Malang, Vol.7 No.1, 2019.

[5] Hootsuite (We are Social), "Digital Around The World in 2019: Indonesian Digital Report".

[6] N. Y. Ferdiani, M. Baiquni, J. Purwohandoyo, "Strategi Penghidupan Pelaku Usaha Pariwisata Kawasan Banten Lama Di Desa Banten, Kecamatan Kasemen, Kota Serang," Jurnal Bumi Indonesia, Volume 5, Nomor 2, 2016.

[7] H. Surasa, M.P Lukman, \& Hasrawati, "Aplikasi Pemandu Wisata Kabupaten Kepulauan Selayar Menggunakan Google Maps API Pada Platform Android," Journal UIN Alaudin, 2018.

[8] R.F. Ningrum, K. Djunaidi, \& F.P. Mahmud, "Tour Guide Application System Sebagai Alternatif Untuk Meningkatkan Kunjungan Wisatawan Di Daerah Sumatera Barat," Jurnal Ilmiah FIFO, Vol. X No.1, 2018.

[9] S. Permana, \& A. Imaduddin, "Menjadi Android Developer Expert," Dicoding, Android Associate, Bandung, 2018.

[10] D. Naista, "Codeigniter Vs Laravel," CV. Lokomedia, Yogyakarta, 2017.

[11] D. Jacobson, G. Brail, \& D. Woods, "APIs: A Strategy Guide," O’Reilly Media, 2012.

[12] Y. Kristiana, P. Sinulingga, \& R. Lestari, "Kunci Sukses Pemandu Wisata," Deepublish, Yogyakarta, 2017.

[13] Suendri, "Implementasi Diagram UML (Unified Modelling Language) Pada Perancangan Sistem Informasi Renumerasi Dosen Dengan Database Oracle," ALGORITMA: Jurnal Ilmu Komputer dan Informatika, 03, 2-3, 2018.

[14] E. Kurniawan, "Implementasi Rest Web Service Untuk Sales Order Dan Sales Tracking Berbasis Mobile," Jurnal EKSIS, Vol 7, No 1. 2014.

[15] A.B. Warsito, A. Ananda, \& D. Triyanjaya, "Penerapan Data JSON Untuk Mendukung Pengembangan Aplikasi Pada Perguruan Tinggi Dengan Teknik Restfull Dan Web Service," Technomedia Jurnal. Vol.2, No.1, Edisi Agustus, 2017. 